\title{
The Intersection Of State And Civil Society In The Media Policy Reform: The Case Of Rri And Tvri
}

\author{
Masduki \\ Department of Communication, Universitas Islam Indonesia, Yogyakarta, Indonesia (Lecturer) \& The University \\ of Munich, Germany (Ph.D. Candidate) $\square$ \\ E-mail: masduki@hotmail.com
}

\begin{abstract}
The reform of media system in the new democracies is a result of political democratizing after the collapse of authoritarians around the 1990s which involves both State and civil society. This paper traces efforts of civil society organizations (CSO) in Indonesia to reform media system during the last $\mathbf{1 5}$ years and their conflict with the ruling power with Indonesian former state-owned broadcasters (Radio \& Television of the Republic of Indonesia or RRI and TVRI) as a case study. Moreover, this paper examines failures of the initiatives in formulating of a truly public service broadcasting (PSB) model.

From an extensive study of current relevant documents, this paper found, CSOs have played an oppositional position, rather than symbiotic action with the State. They influence the policy agenda to change RRI and TVRI status from state to public broadcasters via the new Law. However, as happened in the former authoritarian countries of Asia, the initiative was limited only to the formal policy adoption and lacks control over the policy execution. In the weak of CSOs pressure to the implementation of the Broadcasting Act of 32/2002 and amidst high political intervention of the ruling power during the last 15 years, the change of RRI and TVRI to be a truly PSB was very slow.

This paper contributes to map out CSOs engagement over the media system reform in Indonesia and to address future model of CSO collaboration in the public policies, particularly in a broadcasting sector as a public good.
\end{abstract}

Keywords- Civil Society, State, Policy, Public Broadcasting, Indonesia

\section{REORGANIZING BROADCASTING SYSTEM}

In the last fifteen years, studies of the engagement of civil society organization (CSO) on the media policy formation are growing. In the newly democratic countries in the Eastern Europe and Asia, the position of CSO over broadcasting system reform is much studied in its relation to the process of advocating political policies in the parliament, resulting in a formal form of law and changing the status of former state broadcasting $[1 ; 2 ; 3]$. For example, a study of the CSO contribution to regulating Thai Public Broadcasting
[4;5]. In this country, the idea of establishing an independent public-oriented broadcasting was initiated by academics, media and professional activists since 2007, by acquiring television channel owned by former prime minister Thaksin Shinawatra. On a broader issue, the same situation applies to the revision of the Indonesian Broadcasting Act during 1999-2002 [6;7].

However, studies which focused on both policy and institutional reform of the former state broadcasters in Indonesia, namely RRI and TVRI are still rare, partly on the contribution of CSO. Therefore, this essay hopes to fill the gap. This paper will analyze the intersection of interests between CSOs and the government, in the process of broadcasting law revision no. 24/1997 after the fall of Suharto regime in 1998 to date in Indonesia. The unit of analysis is Law 32/2002 on Broadcasting and its execution period during 2002present. The questions to be answered are: what are the CSOs and their proposals on the future of RRI and TVRI in the Broadcasting Law 32/2002, and its implementation period? To what extent their ideas were championed? What were the weaknesses of CSOs effort? The paper further examines the interaction of CSOs with the ruling government in the regulatory process.

The paper is based on an analysis of empirical documents. It begins with an introduction to broadcasting system reform in the post-autocratic countries, the concept of public service broadcasting (PSB), CSO and media policy. Then, I will describe CSOs and their agendas related to the RRI-TVRI (the radio and television of the Republic of Indonesia) in two stages: the formulation of the Broadcasting Act in 1999-2002 and its execution during 2003-present. The essay will be ended by recommendation on the ways forward.

\section{CSO, State, and Broadcasting Policy}

Broadcasting is the contested arena of political interests due to its strategic position in forming public opinion. With the widest service network, PSBs are considered as the major broadcasting institution, in addition to private and 
community models. For example, BBC in UK and $\mathrm{ABC}$ in Australia. Among the important features of PSB are: its publicly owned and funded with interest to serve public needs. This model is to opposite the private-oriented broadcasting, managed by individuals or commercial corporations. Within the framework of democratic society in Indonesia, RRI and TVRI can be a balancer over the highest political intervention to private channels during the last five years.

In the media policy sector, political systems and political actors influence what form and how the choice of both media institution and their content [8]. In this sense, Smith [2]. And Abbot [9] argued the role of CSOs is significant in the process of the policy formation to oppose newly governments in the former authoritarian regimes. For example, in the Eastern Europe and Asia, Abbot and Smith highlighted collaboration among local CSOs with global aid agencies in the formulation of broadcasting policies, such as the UNESCO, the AIBD, INTERNEWS and Article 19 in Indonesia.

The notion of CSO in the political science literature is very broad, and for this essay, I refer it as the group of non-state actors articulating ideas and engaging in the policy formation for the public interest [10]. CSOs in which grew up in postauthoritarian countries were seen as strategic actors, a model of public interaction dealing with a newly authoritarian regime of government. Following Thomson's logic [11], there are at least two political positions of the CSOs: oppositional to government and/or symbiotic. However, the current political position now is more diverse than in the authoritarian politics.

In the policy advocacy, two strategies were mostly adopted by CSOs, namely raising up the issue of media reform through seminars, media exposures, and lobbying; and technical assistances to draft a new law or to govern PSB channel. Abbot [9] for example noted the involvement of the Open Society Foundation in Asia and Africa applying the two strategies. For the advocacy of regulation in parliament, Majone [12] identifies two stages: First, a policy formulation step comprising the setting and negotiation of public agenda. Second, the execution step (formation of lower policies and field action).

\section{Struggles Between CSOs and the State}

This section describes the constellation of CSOs and their contestation with the state officials in two important moments: formulation and implementation of the broadcasting law. Partly, it focuses to the four CSOs: The first two CSOs are Indonesian Society of Press and Broadcasting (MPPI), and media academics who called 'Depok School' (chaired by Effendi Gazali and Suko Widodo). With some RRI and TVRI broadcasters, they organized workshops in 10 cities of Indonesia along 2000-2001 and then drafted the Broadcasting Bill. The other two CSOs are Independent Group for Broadcasting Democracy (KIDP) Jakarta and Clearing House of Indonesia PSB (RPLPP) in Yogyakarta. Both institutions will be discussed as the monitory agents of the RRI-TVRI as public broadcasters.

During formulation of a new Broadcasting Act in 1999-2002, the government was represented by the Ministry of Communication and Information Technology (MCIT), while the public was voiced by the first two CSOs. Both parties raised their proposals on four crucial issues of RRI-TVRI: remit, ownership, structure, and funding models.

For instance, on the issue of ownership and structure, the MCIT recommended that RRI and TVRI should be a state agency under government control in which bring back them into past autocratic model. In contrast, CSOs preferred the adopt an independent, publicly-owned and nonprofit models, established by the State in the name of the public. In governing structure, they proposed that the Supervisors board should be elected by the parliament [13;7]. It can be said, the position of CSOs was oppositional to the wishes of MCIT. Moreover, the table below outlines both position and strategy of CSOs:

Table 1. Policy Formulation Period: 1999-2002

\begin{tabular}{|c|c|c|c|}
\hline CSO & Goal & Proposal & Strategy \\
\hline $\begin{array}{l}\text { Society of } \\
\text { Press \& } \\
\text { Broadcasti } \\
\text { ng, Jakarta }\end{array}$ & $\begin{array}{l}\text { Democratic } \\
\text { norms: } \\
\text { diversity of } \\
\text { ownership } \\
\text { and content, } \\
\text { including the } \\
\text { change of } \\
\text { RRI and } \\
\text { TVRI to } \\
\text { PSB }\end{array}$ & $\begin{array}{l}\text { RRI and TVRI } \\
\text { run } \\
\text { independently } \\
\text { for public and } \\
\text { are financed by } \\
\text { both state } \\
\text { budget and } \\
\text { license fee }\end{array}$ & $\begin{array}{c}\text { Seminar } \\
\text { and Law } \\
\text { drafting; } \\
\text { Parliame } \\
\text { nt } \\
\text { lobbying }\end{array}$ \\
\hline $\begin{array}{l}\text { Communi } \\
\text { cation } \\
\text { Academic } \\
\text { s: Depok } \\
\text { School, } \\
\text { Jakarta }\end{array}$ & $\begin{array}{l}\text { Strengthenin } \\
\text { g the } \\
\text { important of } \\
\text { PSB and } \\
\text { changes of } \\
\text { RRI and } \\
\text { TVRI as } \\
\text { well }\end{array}$ & $\begin{array}{l}\text { RRI and TVRI } \\
\text { run the mission } \\
\text { for public } \\
\text { interest and are } \\
\text { financed from } \\
\text { public funding }\end{array}$ & $\begin{array}{c}\text { National } \\
\text { worksho } \\
\text { p in } \\
\text { cooperat } \\
\text { ion with } \\
\text { RRI \& } \\
\text { TVRI }\end{array}$ \\
\hline
\end{tabular}

[Source: 14;15]

All debates have influenced the formation of the final law in its enactment in the House of Parliament by November 28, 2002. Unfortunately, the Act was not totally in favor of public interest. Within 64 articles in Broadcasting Act no. 32/2002, the PSB governance is regulated by only five articles. The first article recognizes PSB as one of four models alongside private, community and pays broadcasting systems. The second article rules ownership, mandate, and structure of Indonesian 
PSB. It describes RRI and TVRI as a public based entity that should formally be managed as an independent non-profit body with the remit to serve entire publics.

The other three articles regulate financial sources, among other from license fees, the state budget, and advertising. Some CSO proposals were broadly accommodated, but with no details provision on the new RRI-TVR, I model [16].

Furthermore, during the period 2002-2008, there was a vacuum of CSOs focusing to monitor the execution of the law. In contrast, the new regimes have managed to consolidate political power with their agenda that oppose public interest. For instance, the position of Ministry of Communication and Informatics (MCIT), as well as politicians, are getting stronger to intervene RRI and TVRI through various rooms such us annual budget allocation, selection of the Supervisory Board and the employee recruitment [16]. This resulted in the slow process of an implementation of the PSB norms.

The two new CSOs have emerged finally by the end of the 2000s, namely Independent Group for Broadcasting Democracy (KIDP) in Jakarta and the Clearing House of Indonesia PSB (RPLPP) in Yogyakarta. They benefitted from the opportunity to gain public debate through the plan of Broadcasting Law revision and the idea to adopt a special law for RRI and TVRI, namely RTRI Bill which publicized around 2011-present. The table below explores proposals and advocacy strategies pursued by both institutions:

Table 2. Policy Implementation Period: 2003-

$$
2017
$$

\begin{tabular}{|c|c|c|c|}
\hline CSO & Goal & Proposal & Strategy \\
\hline $\begin{array}{c}\text { Independent } \\
\text { Coalition of } \\
\text { Broadcasting } \\
\text { Democratizat } \\
\text { ion, } \\
\text { Jakarta }\end{array}$ & $\begin{array}{l}\text { Maintain a } \\
\text { pro-public } \\
\text { broadcastin } \\
\text { g system } \\
\text { including } \\
\text { monitoring } \\
\text { the } \\
\text { performanc } \\
\text { e of RRI- } \\
\text { TVRI }\end{array}$ & $\begin{array}{l}\text { A balance } \\
\text { of the } \\
\text { existing } \\
\text { broadcaste } \\
\text { rs, the } \\
\text { independe } \\
\text { nce of } \\
\text { RRI-TVRI } \\
\text { manageme } \\
\text { nt }\end{array}$ & $\begin{array}{l}\text { Public } \\
\text { statement, } \\
\text { and lawsuit } \\
\text { to the } \\
\text { Constitutio } \\
\text { nal Court }\end{array}$ \\
\hline $\begin{array}{c}\text { Clearing } \\
\text { House for } \\
\text { Indonesian } \\
\text { PSB, } \\
\text { Yogyakarta }\end{array}$ & $\begin{array}{l}\text { Mainstream } \\
\text { ing PSB } \\
\text { issues, audit } \\
\text { over the } \\
\text { performanc } \\
\text { e of RRI } \\
\text { and TVRI } \\
\text { and } \\
\text { encouragin } \\
\text { g their } \\
\text { governance } \\
\text { reform }\end{array}$ & $\begin{array}{l}\text { Changes } \\
\text { in the } \\
\text { overall } \\
\text { governanc } \\
\text { e, audits, } \\
\text { the need } \\
\text { for special } \\
\text { PSB law }\end{array}$ & $\begin{array}{c}\text { Series of } \\
\text { workshops, } \\
\text { social } \\
\text { media } \\
\text { campaigns, } \\
\text { public over } \\
\text { PSB } \\
\text { performanc } \\
\text { e and, } \\
\text { drafting } \\
\text { bill of } \\
\text { RTRI }\end{array}$ \\
\hline
\end{tabular}

[Source: 16]

\section{In The Need of Strong Collaboration}

In short, there was the conflictualoppositional intersection between CSOs and the ruling power, particularly in two periods: policy formation of Broadcasting and its execution during 1999-present. On the first period, the position of CSOs was tended to be strong due to the weak of the new regime's powers. On the contrary, in the post 2002-present, the CSO efforts were weakened. As a result, the formulation of PSB provision in the Broadcasting Law was relatively good. However, the reform of RRI and TVRI from the State control to Public owned and public-oriented broadcasting was very slow. To learn from the past successful formulation of the Broadcasting law (1999-2002), there is the need of strong collaboration of local and international CSOs as well as RRI-TVRI broadcasters in the implementation step of the Law and in the present initiatives to formulate RTRI law.

\section{References}

[1.] K. Jakobuwicz, Finding the Right Place on the Map, Central and Eastern European Media Change in a Global Perspective (Intellect Books, Bristol, 2008)

[2.] E. Smith, A Road Map to Public Service Broadcasting (UNESCO and AIBD, Kuala Lumpur, 2012)

[3.] I. Banerjee, \& S. Kalinga, Public Service Broadcasting, A Best Practices Sources (AMIC-UNESCO, Singapore, 2005)

[4.] S. Tangkitvanich, The Creation of Thai Public Broadcasting Service (TDRI Quarterly Review Vol. 23, no. 2, 2008)

[5.] M. Green, Media Regulation in Mekong and Opportunities for the Development of Public Service and Community Broadcasting (UNESCO, Bangkok Office, 2013)

[6.] P. Kitley, Reformasi, Vulnerable Values and the Regulation of TV in Indonesia (Asia Pacific Media Educator, No. 8, 2000, page 132-148)

[7.] Masduki, Broadcasting Regulation, From Authoritarian to Liberal (Institute of Islamic and Social Studies, Yogyakarta, Indonesia, 2007)

[8.] D. Hallin, \& P. Mancini, Comparing Media System, Three Models of Media and Politics (Cambridge University Press, London, 2004)

[9.] S. Abbot, Susan, Rethinking Public Service Broadcasting's Place in International Media Development (CIMA, Washington, 2016)

[10.] B. Verena, (Un)civil Society and Political Change in Indonesia, A Contested Arena (Routledge, Canada, 2010)

[11.]M. Thomson, Civil Society, and Democracy: Toward a Taxonomy, in Ganesan, N \& Durkop, Colin, (Ed.), Civil Society and Democracy in South East Asia (Konrad Adenauer Stiftung, Ankara, 2015) 
[12.]G. Majone, Evidence, Argument, and Persuasion in the Policy Process (Yale University Press, Connecticut, 1992)

[13.] W. Maimun Irma, Social Construction of Public Broadcasting, Political Economy Analysis of Broadcasting Act, 32/2002, (Indonesian University, Jakarta, 2003)

[14.] Masyarakat Pers dan Penyiaran Indonesia, Naskah Akademik dan Draft RUU Penyiaran (MPPI, Jakarta, 1999)

[15.]E. Gazali, Negotiating Public and Community Media (The Public Journal, Vol. 1, no. 1, 2003, page 85-100)

[16.] Masduki \& Darmanto, Save RRI, and TVRI, Inisiatif Masyarakat Sipil Untuk Transformasi Lembaga Penyiaran Publik di Indonesia (Rumah Perubahan Lembaga Penyiaran Publik and Yayasan Tifa, Yogyakarta, 2014) 